\title{
Perancangan Sistem Informasi Menejemen Sarana Dan Prasarana Menggunakan Framework Codeigniter Pada Akademi Ilmu Komputer Ternate
}

\author{
Ratna Jafar ${ }^{1}$, Muksin Hi. Abdullah', Mudar Safi ${ }^{3}$ \\ Program Studi Teknik Komputer \\ Akademi Ilmu Komputer Ternate \\ ratnajafar13@gmail.com
}

\begin{abstract}
Abstrak
Pengelolaan sarana dan prasarana sangat penting karena dengan adanya pengelolaan sarana prasarana yang ada di lembaga pendidikan akan terpelihara dan jelas kegunaannya. Dalam pengelolaannya suatu instansi harus dapat bertanggung jawab terhadap sarana prasarana sehingga diharapkan akan berdampak positif terhadap seluruh keberlangsungan mahasiswa dalam proses belajar mengajar dan agar tujuan pendidikan dapat tercapai secara efektif dan efisien, maka para penyelenggara pendidikan perlu berusaha untuk terus-menerus meningkatkan kualitas pendidikan sesuai dengan tuntutan zaman. Banyaknya fasilitas dan keperluan dimana satu sama lain saling berkaitan dan harus terorganisir dengan baik maka informasi tentang administrasi sebenarnya dapat diposting dalam sebuah media sehingga dapat diakses oleh semua orang/mahasiswa ataupun satker lain melalui internet, sehingga memberikan ide bagi penulis untuk membuat suatu website dengan menggunakan pemrograman PHP dan $M y S Q L$ sebagai basis datanya dilengkapi dengan Framework Codeigniter dengan tujuan dapat memberikan kemudahan pihak manajemen AIKOM Ternate dalam mengelola sarana dan prasarana, sehingga mempermudah proses pelaporan nantinya.
\end{abstract}

Kata Kunci: Framework Codeigniter, PHPMyAdmin, MySQL, Xampp, AIKOM Ternate

\begin{abstract}
Management of facilities and infrastructure is critical because there are infrastructure management facilities available in educational institutions that will be maintained and their use bright. In its management there must be accountability for infrastructure so that it must have a positive impact on the sustainability of students in the teaching and learning process and so that educational goals can be effectively and efficiently improved, organizers need the education needed to continuously improve the quality of education by the rescue of the times. There are so many facilities and needs where each other is interrelated and must be well organized, information about administration can be posted on media that can be accessed by all people/students or other work units through the internet, thus providing ideas for writers to create a site web using PHP and MySQL programming as a database equipped with a Codeigniter Framework to provide the ease of management of AIKOM Ternate in managing facilities and infrastructure, thereby facilitating the resulting reporting process.
\end{abstract}

Keywords: Codeigniter Framework, PHPMyAdmin, MySQL, Xampp, AIKOM Ternate

\section{PENDAHULUAN}

Pengelolaan sarana dan prasarana sangat penting karena dengan adanya pengelolaan sarana prasarana yang ada di lembaga pendidikan akan terpelihara dan jelas kegunaannya. Dalam pengelolaannya suatu instansi harus dapat bertanggung jawab terhadap sarana prasarana terutama kepala bagian yang langsung menangani tentang pengelolaan sarana prasarana ter- 
sebut. Dan pihak Universitas pun harus dapat memelihara dan memperhatikan sarana prasarana yang sudah ada. Maka dengan adanya sarana prasarana, mahasiswa pun dapat belajar dengan maksimal dan seefisien mungkin.

Dengan pengelolaan sarana prasarana kepala bagian dapat merencanakan dan mendata apa saja sarana prasarana yang harus digunakan dalam instansi tersebut. Jika semua langkah-langkah pengelolaan telah berjalan dengan baik seperti yang diharapkan maka akan berdampak positif terhadap seluruh keberlangsungan mahasiswa dalam proses belajar mengajar dan agar tujuan pendidikan dapat tercapai secara efektif dan efisien, maka para penyelenggara pendidikan perlu berusaha untuk terus-menerus meningkatkan kualitas pendidikan sesuai dengan tuntutan zaman.

Saat ini untuk pengolahan sarana dan prasarana pada AIKOM Ternate masih dilakukan secara convesional sehingga dalam pengolahan data masih kurang efektif sehingga dengan banyaknya fasilitas dan keperluan satu sama lain saling berkaitan dan harus terorganisir dengan baik maka informasi tentang administrasi sebenarnya dapat diposting dalam sebuah media sehingga dapat diakses oleh semua orang/mahasiswa ataupun satker lain melalui internet, sehingga memberikan ide bagi penulis untuk membuat suatu website yang bisa memberikan informasi bagi para pengunjungnya. Berdasarkan masalah dan latar belakang yang terurai diatas, penulis bermaksud untuk membuat Sistem Informasi Sarana dan Prasarana Berbasis web dengan menggunakan Framework Codeigniter untuk dapat memberikan infromasi terkait jumlah sarana dan prasarana yang ada beserta jadwal pemakaian dan peminjaman dan juga laporan pertahun tentang fasilitas yang ada di AIKOM Ternate.

\section{Rumusan Masalah}

1. Bagaimanakah Proses Perancangan sistem informasi Sarana dan Prasarana di Akademi Ilmu Komputer Ternate?

2. Bagaimana implementasi sistem informasi Sarana dan Prasarana di Akademi Ilmu Komputer Ternate dalam memberikan informasi mengenai Jadwal Pemakaian maupun Peminjaman sarana dan Prasarana yang tersedia?

\section{Tujuan Penelitian}

Tujuan penelitian ini adalah untuk menganalisis, merancang dan membuat perancangan Sistem Informasi Sarana dan Prasana Berbasis Web.

\section{Manfaat Penelitian}

1. Diharapkan dengan adanya penelitian ini maka akan menjadi kajian pustaka dan landasan bagi para peneliti untuk lebih mengembangkan Sistem ini kedepannya.

2. Memberikan kemudahan pihak manajemen AIKOM Ternate dalam mengelola sarana dan prasarana, sehingga mempermudah proses pelaporan nantinya.

\section{Tinjauan Pustaka}

Penelitian yang dilakukan oleh (Munjid, 2013) dengan judul Sistem Informasi Pendataan Kegiatan Fisik sarana dan Prasarana Pada Kantor Unit Pengelola Kegiatan Program Nasional Pemberdyaan Masyarakat Mandiri Pedesaan Kecamatan Tegallombo Kabupaten Pacitan. Sistem yang dikembangkan lebih kepada proses Pengelolaan Pendataan Kegiatan, yang 
mana selama ini prosesnya masih dilakukan secara manual sehingga menghambat proses pelaporan

Pada penelitian yang dilakukan oleh (Imtihanah, 2014) dalam penelitiannya tentang Sistem Informasi Sarana dan Prasarana Sesuai Standar BAN-PT Terintegrasi SISFO-KAMPUS 4.1 Dalam penelitian ini peneliti mengidentifikasi masalah yang timbul dalam pengelolaan sarana dan prasarana di Institut Agama Islam Ibrahimy Sukorejo Situbondo dimana proses pendataan masih menggunakan cara-cara manual. Penelitian ini menggunakan Bahasa Pemrograman PHP dan MySQL yang menghasilkan suatu aplikasi untuk memudahkan pendataan sarana dan prasarana yang ada.

Pada penelitian yang dilakukan oleh (Cholifah dkk, 2017) dalam penelitiannya tentang Perancangan Sistem Informasi Pendataan Sarana dan Prasana Sekolah Pada Sekolah Dasar Islam Terpadu IQRA. Penelitian ini membahas mengenai pentingnya sarana dan prasarana untuk menunjang proses belajar mengajar. Bahasa Pemrograman yang digunakan yaitu PHP dan database MySQL.

\section{LANDASAN TEORI}

\section{Pengertian Sistem Informasi}

Sistem Informasi adalah sistem di dalam suatu organisasi yang mempertemukan kebutuhan pengolahan transaksi harian yang mendukung fungsi operasi organisasi yang bersifat manajerial dengan kegiatan strategi dari suatu organisasi untuk dapat menyediakan kepada pihak luar tertentu dengan laporan yang diperlukan (Sutabri, 2012).

\section{Pengertian Sarana dan Prasarana}

Daryanto (2008: 51) secara bahasa yang disebut dengan prasarana berarti alat yang tidak langsung digunakan untuk mencapai tujuan dalam pendidikan misalnya : lokasi atau tempat, bangunan sekolah, lapangan olahraga, uang dan sebagainya

\section{Pengertian CodeIgniter}

CodeIgniter adalah sebuah framework PHP yang dapat membantu mempercepat developer dalam pengembangan aplikasi web berbasis PHP disbanding jika menulis semua code program dari awal (Hakim, 2010).

\section{Flowchart}

Menurut Indrajani (2011:22), Flowchart merupakan penggambaran secara grafik dari langkah-langkah dan urutan prosedur suatu program, Biasanya mempengaruhi penyelesaian masalah yang khusunya perlu dipelajari dan dievaluasi lebih lanjut..

\section{Diagram Konteks}

Menurut Kristanto (2011:55), "Diagram Konteks adalah suatu model logika data atau proses yang dibuat untuk menggambarkan darimana asal data dan kemana tujuan data yang keluar dari sistem, dimana data disimpan, proses apa yang menghasilkan data tersebut dan interaksi antara data yang tersimpan dan proses yang dikenakan pada data tersebut.

\section{Entity Relation Diagram (ERD)}

Menurut Rosa dan Shalahuddin (2015:53) " ERD adalah bentuk paling awal dalam melakukan perancangan basis data relasional. Jika menggunakan OODMBS maka perancangan ERD tidak perlu dilakukan". Sedangkan menurut Ladjamudin (2013:142) "Entity Relationship Diagram (ERD) adalah suatu model jaringan yang menggunakan susunan data yang disimpan dalam sistem secara abstrak". 
METODE PENELITIAN

\section{Metode Pegumpulan Data}

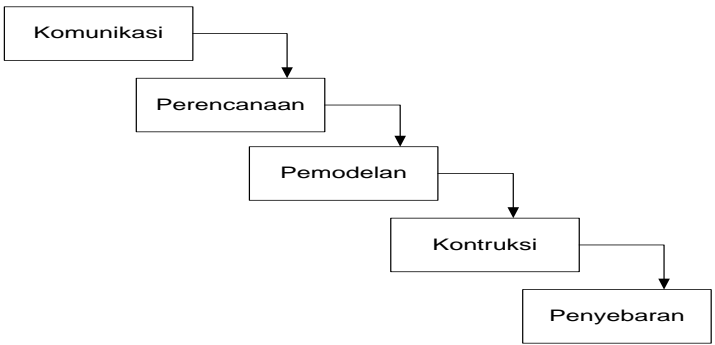

Gambar 1. Waterfall Model

Metode pengembangan perangkat lunak yang digunakan dalam penelitian ini adalah metode dengan model waterfall. Model Waterfall bekerja tahap demi tahap. Dimana tahap yang dilalui harus menunggu selesainnya tahap sebelumnya dan berjalan berurutan. Model Waterfall ini melakukan pendekatan sistematis dan urut mulai dari tahap Communication (Komunikasi), Planning (Perencanaan), Modeling (Pemodelan), Construction (Penerjemahan), dan Deployment (Implementasi/Pemeliharaan). Pada tahapan terakhir yaitu Deployment, sistem digunakna oleh pengguna secara nyata dan pengguna akan memberikan umpan balik sebagai saran penambahan fitur, serta perbaikan kesalahan. Apabila ada penambahan fitur dan perbaikan kesalahan, maka penelitian dikembalikan ke tahapan sebelumnya. Apabila kesalahan yang akan diperbaiki pada tahapan tersebut, maka penelitian dikembalikan ke tahap yang sebelumnya.

\section{Komunikasi (Communication)}

Sangat penting berkomunikasi dengan pengguna yang ada di Akademi ilmu Komputer Ternate untuk memahami tujuan sistem dan mengumpulkan data yang diperlukan untuk membantu mendefenisikan fitur-fitur yang akan dibuat pada sistem informasi manajamen sarana dan prasarana.

\section{Perencanaan (Planning)}

Perencanaan mendefenisikan kerja sistem dengan menjelaskan cara kerja dari sistem dan sumber daya yang membantu memberikan data-data alumni yang diperlukan dalam proses pembuatan sistem.

\section{Pemodelan (Modeling)}

Pemodelan pada Sistem Informasi manajemen sarana dan prasarana dimulai dengan pembuatan flowchart yang diusulkan, pembuatan data flow diagram (DFD), perancangan basis data dan perancangan tampilan untuk input dan output.

4. Kontruksi (Construction)

Tahapan kontruksi ini merupakan proses penerjemahan bentuk desain menjadi kode, pada pengkodean sistem yang telah dibuat (penulisan kodingnya). Bahasa pemograman yang digunakan yaitu PHP dan $M y S Q L$ sebagai databasenya.

5. Penyebaran (Deployment)

Penggunaan sistem dimana Sistem Informasi Manajemen sarana dan parasarana akan digunakan dan diserahkan kepada bagian yang menggunakan untuk manajemen dan pengelolaan lebih lanjut.

\section{ANALISIS DAN PERANCANGAN Analisis Sistem Yang Diusulkan}

Pada analisis yang diusulkan terdapat tiga (3) entitas yaitu pengguna, staf dan impinan. Pengguna dapat melihat informasi sarana dan prasarana yang tersedia, selanjutnya melakukan permohonan sarana dan prasarana kepada staf. Selanjutnya staf akan mencetak permohonan dari penggguna dan mengkonfirmasi kembali ke pengguna. Selanjutnya staf menginput jadwal peminjaman. Hasil laporan akan disampaikan kepada pimpinan. 


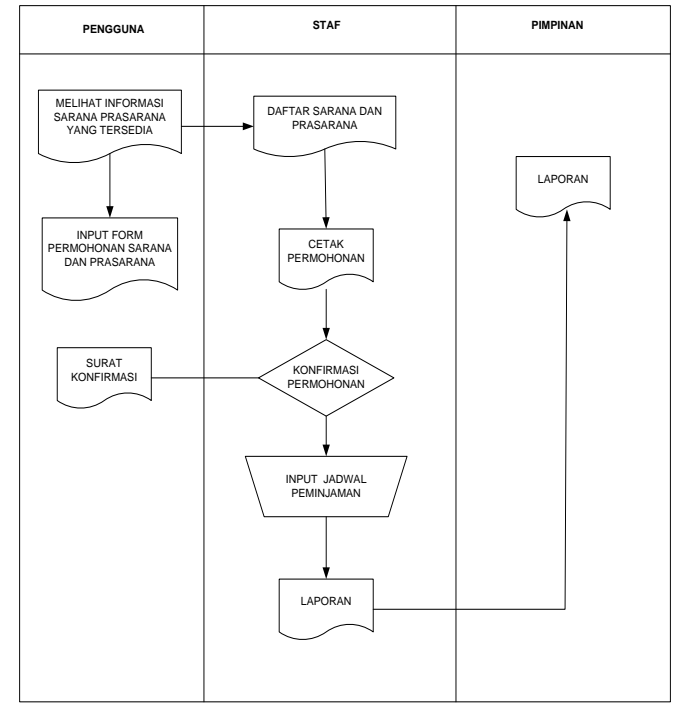

Gambar 2. Sistem yang Diusulkan

\section{Diagram Blok Sistem}

Diagram blok sistem menggambarkan setiap blok atau bagian dari sistem informasi sarana dan prasarana.

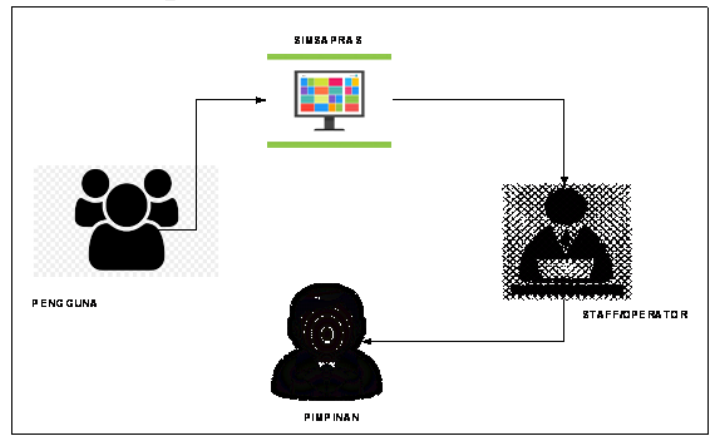

Gambar 3. Diagram Sistem

\section{Diagram Konteks}

Diagram blok sistem menggambarkan setiap blok atau bagian dari sistem informasi sarana dan prasarana.

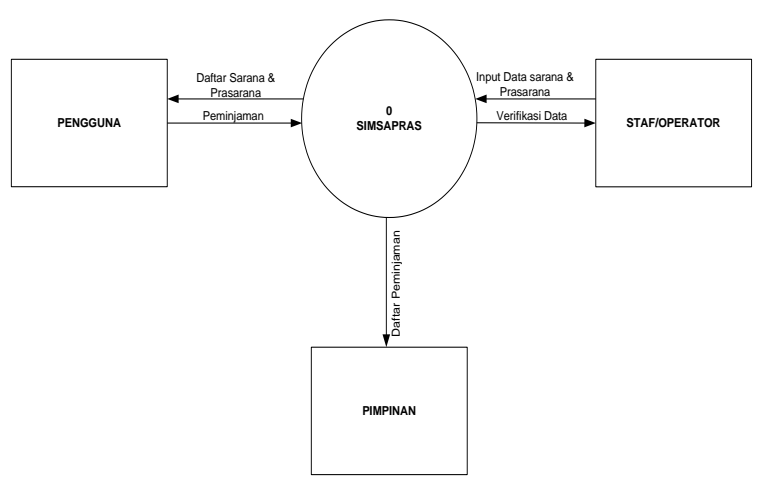

Gambar 4. Diagram Konteks

\section{Perancangan Basis Data}

\begin{tabular}{|c|c|c|c|c|}
\hline $\begin{array}{l}\text { Tabel Peminjaman } \\
\text { Nama tabel : pemin } \\
\text { Fungsi : Penyi } \\
\text { Tabel } 31 \text { Tabel Pem }\end{array}$ & $\begin{array}{l}\text { nan } \\
\text { anan data } \\
\text { aman }\end{array}$ & peminjan & & \\
\hline nama & Type & Width & Index & keterangan \\
\hline Id & Int & 11 & Primary key & Id \\
\hline Prasarana_id & Varchar & 11 & & Id prasarana \\
\hline Nama & Varchar & 100 & & Nama Prasarana \\
\hline Lembaga & Varchar & \begin{tabular}{|l|}
100 \\
\end{tabular} & & Nama Lembaga \\
\hline email & Varchar & 50 & & Email \\
\hline No_Telp & Varchar & 30 & & No Telp \\
\hline Kegiatan & Varchar & 255 & & Nama Kegiatan \\
\hline Tgl_mulai & Date & & & Tgl Mulai \\
\hline Tgl_selesai & Date & 100 & & Tgl Selesai \\
\hline Jam_mulai & Varchar & 100 & & Jam Mulai \\
\hline Jam_selesai & Time & 100 & & Jam Selesai \\
\hline File & Time & 100 & & Nama File \\
\hline asal & Varchar & 20 & & Asal \\
\hline Status_pinjam & Int & \begin{tabular}{|l|}
11 \\
\end{tabular} & & Status Pinjam \\
\hline Status prasarana & Int & $\mid 11$ & & Status Prasarana \\
\hline
\end{tabular}

Gambar 5. Kamus Data

\section{Entity Relationship Diagram}

Merupakan diagram yang di pergunakan untuk mengambarkan hubungan antara Entity dalam suatu system yang akan di buat dalam hal ini Sistem Informasi Sarana dan Prasarana di Akademi Ilmu Komputer Ternate.

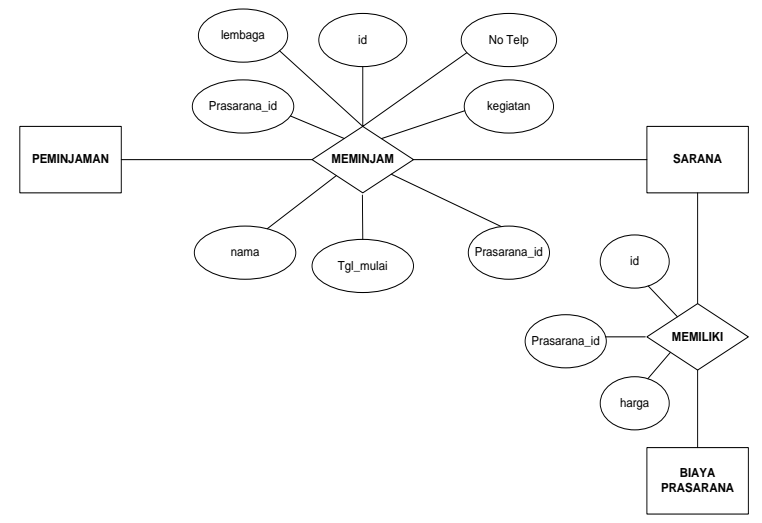

Gambar 6. ERD

\section{Perancangan Antarmuka}

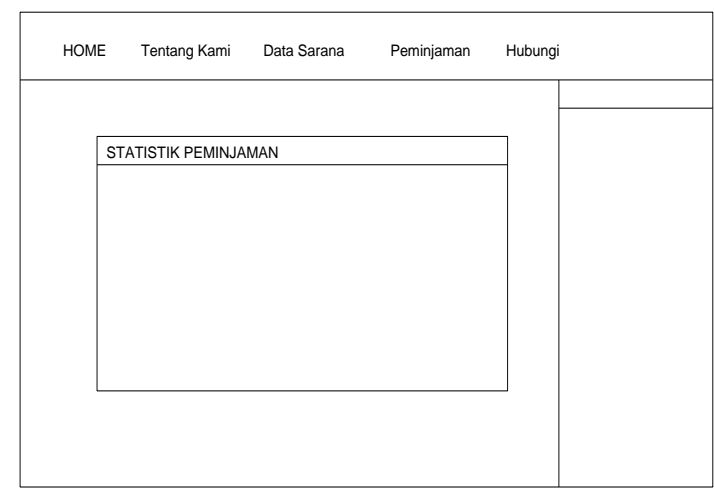

Gambar 7. Rancangan Tampilan Beranda 


\section{IMPLEMENTASI DAN PEMBAHA-} SAN

Form Login ini merupakan tampilan awal pengguna untuk masuk kedalam aplikasi Sistem Informasi Sarana dan Prasarana. Pengguna harus memasukan username dan password untuk dapat masuk ke menu.

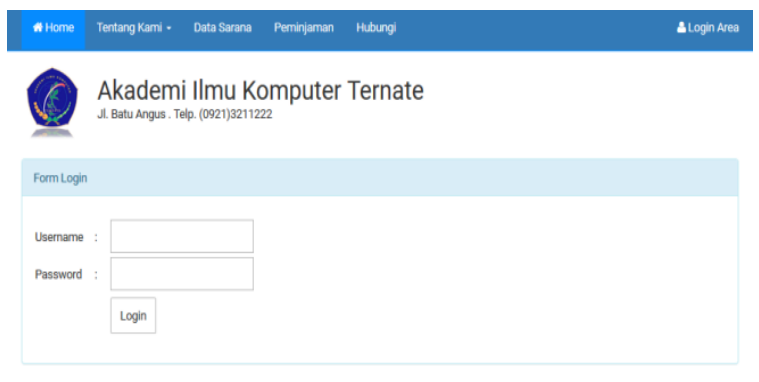

Gambar 8. Form Login

Tampilan Laman Beranda ialah tampilan utama yang didalamnya terdapat statistik, peminjaman sarana. Adapun grafik statistic terdapat jumlah bulan pertahunnya yg akan meningkat, menurun sesuai dengan jumlah pemjaman dilakukan AIKOM Ternate.

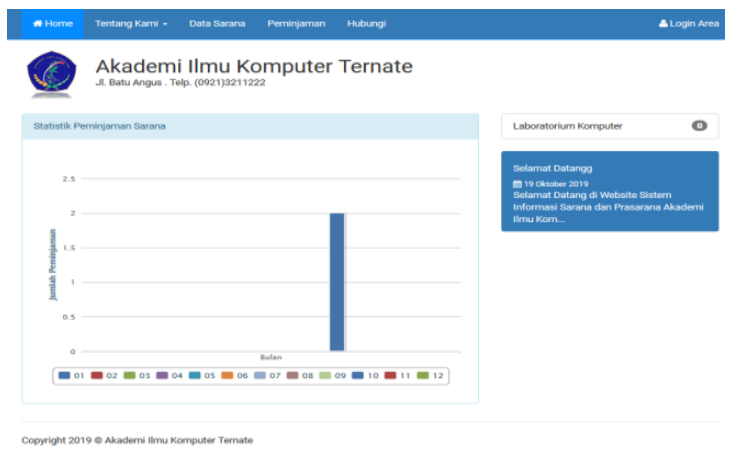

Gambar 9. Form menu utama

Tampilan Data Sarana untuk melihat ada beberapa sarana yang ad di AIKOM Tenate. Pada tampilan data sarana terdapat beberapa field diantarnyano, foto, nama, lokasi, luas, dan kapitas.

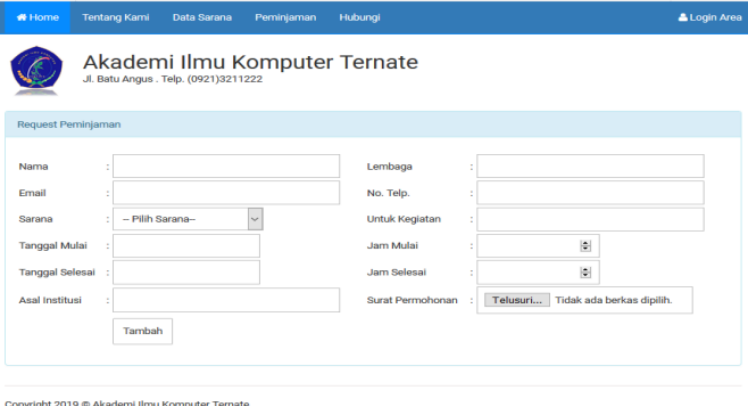

Gambar 10. Tampilan Form Peminjaman

Tampilan Form Peminjaman ini Untuk yang Request peminjaman dan di dalamnya kita harus mengisi berbagai data yg di butuhkan.pada menuh pemijaman terdapat form nama, Email, sarana, tanggal mulai, selesai, asal institusi, lembagi, noma telpon, untuk kegiatan,jam mulai, jam selesai,dan file surat permohonan.

Tampilan Data Sarana untuk melihat ada beberapa sarana yang ad di AIKOM Tenate. Pada tampilan data sarana terdapat beberapa field diantarnyano, foto, nama, lokasi, luas, dan kapitas.

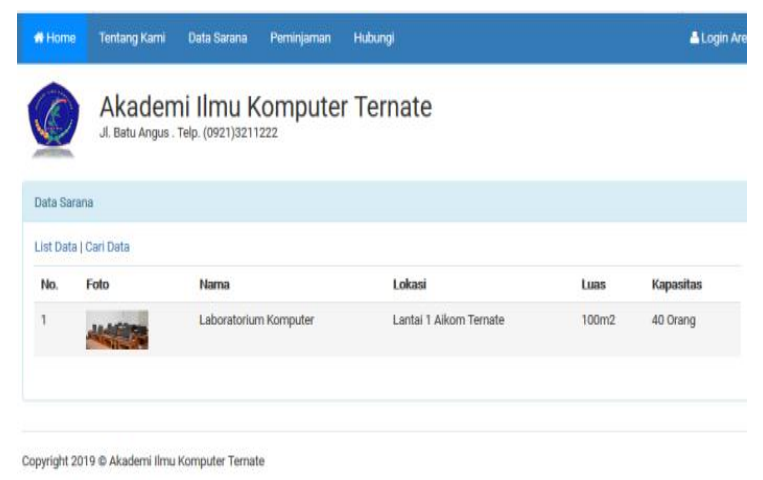

Gambar 11. Laporan Data Sarana

\section{KESIMPULAN}

1. Telah dibuat Sistem Informasi Manajemen Sarana dan Prasarana menggunakan Framework Codeigniter di Akademi Ilmu Komputer Ternate.

2. Program yang dirancang telah dilakukan pengujian secara fungsionalitas terhadap berbagai modul seperti modul data sarana, modul data peminjaman 
dan modul data pengguna dan dapat berjalan dengan baik

\section{Saran}

Tahapan selanjutnya untuk pengemban gan penelitian ini kedepan yaitu mengkoneksikan semua data sarana yang ada di Akademi Ilmu Komputer Ternate menggunakan konsep Mobile Service berbasis Android.

\section{DAFTAR PUSTAKA}

Afidh Razief, 2017. Rancang bangun Sistem Informasi Pendataan Akreditasi Program Studi Universitas Syiah Kuala, ISSN 20889658(http://semnastikom.uniyap.a c.id/download/paper/33186b1078ebae3 510bb51633f965016.pdf). diakses tanggal 4 Agustus 2018.

Cholifah, Nur W, 2017. Perancangan Sistem Informasi Pendataan Sarana dan Prasana Sekolah Pada Sekolah Dasar Islam Terpadu IQRA (http://maklumatika.uniat.ac.id/files/v ol3no2januari2017/008Sapras.pdf). diakses tanggal 20 Agustus 2018.

M. Daryanto. 2006. Administrasi Pendidikan. Jakarta: Rineka Cipta. Cet. IV, hlm.51

Hakim, Lukmanul. 2010. Membangun Web Berbasis PHP dengan Framework Co-deigniter. Yogyakarta: Lokomedia.

Indrajani. (2011). Perancangan Basis Data dalam All in 1, PT. Elex Media Komputindo, Jakarta.

Imtihanah 2014. Sistem Informasi Sarana dan Prasarana Sesuai Standar BANPT Terintegrasi SISFO-KAMPUS 4.1. Skripsi. Universitas Islam Maulana Malik Ibrahim. Malang (http://etheses.uinmalang.ac.id/8106/1 /09650029.pdf), diakses tanggal 23 Agustus 2018

Kristanto, Andri. 2011. Perancangan Sistem Informasi Dan Aplikasinya. Yogyakarta: Gava Media
Kadir, Abdul, 2011. From Zero to Pro HTML 5. Penerbit Andi Yogyakarta .

Leman, 1998. Metodologi Pengembangan Sistem Informasi, Elex Media Komputindo.

Munjid Arum, 2013. Sistem Informasi Pendataan Kegiatan Fisik sarana dan Prasarana Pada Kantor Unit Pengelola

Kegiatan Program Nasional Pemberdyaan Masyarakat Mandiri

Pedesaan Kecamatan Tegallombo Kabupaten Pacitan.

(http://epub.tiunsa.org/index.php/Sist emInform si/article/view/139) diakses tanggal 24 Agustus 2018

A.S., Rosa dan Shalahuddin, M. 2015. Rekayasa Perangkat Lunak Terstruktur dan Berorientasi Objek. Bandung: Informatika Bandung.

Raditya, dkk, 2016. Sistem Dashboard Untuk Persiapan Alreditasi Program Studi Sarjana Berdasrkan Standar $B A N-P T$. Jurnal Sistem Informasi (JSI) Volume 8 nomor 1 ISSN:20851588(https://ejournal.unsri.ac.id/inde x.php/jsi/article/download/2956/1581 ), diakses tanggal 4 Agustus 2018

Sukamto ,Titien, Nugroho. 2016. Desain Sistem Informasi Akreditasi Program Studi Berbasis Website Indones ia(http://journal.uii.ac.id/Snati/article /download/6266/5642) tanggal 3 Agustus 2018

Tata Sutabri. 2012. Analisis SistemInforma si. Andi. Yogyakarta 